\title{
Obituaries
}

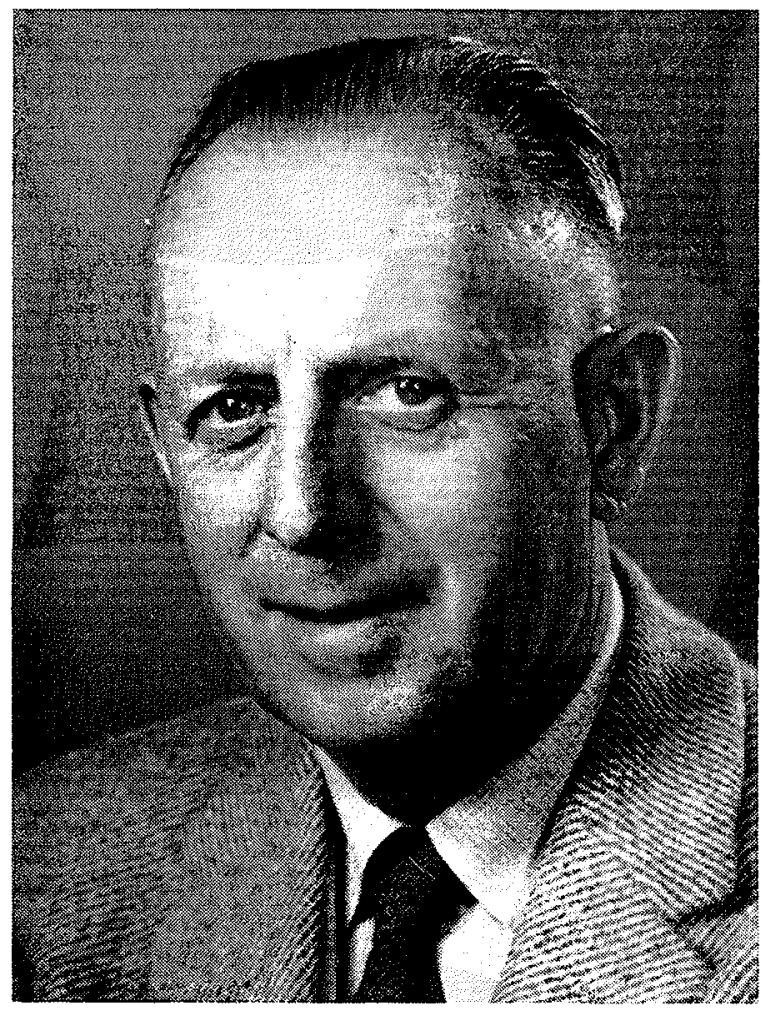

\section{GEORGE SILBURN}

The Vancouver Island Section sadly announces the passing of one of its early members, George Silburn. His shy smile, sharp blue eyes and soft drawling voice will be missed by all who knew him. George was born in England and as a small boy came to Victoria. He was very active in the early years of the Victoria Amateur Swimming Club, when it used to meet at the Gorge and later in the new Crystal Garden. He was also an active member of the Y.M.C.A.

George was 65 years of age. He commenced work in the woods in 1921 when he started timber cruising with Bob and Jack Hibberson who had a great influence on his development as a forester. Later, in 1935, he joined the B.C. Forest Service, with which he worked until he retired last year. During these years he rose to the position of $2 \mathrm{i} / \mathrm{c}$ of the Forest Survey Division (now Forest Inventory Division) and in 1956 to the position of Forester $\mathrm{i} / \mathrm{c}$ of the Reforestation Division.

George didn't change much over the years, and at sixty he wasn't much different from twenty. His nature fitted the work he had chosen. He was a part of nature, the trees, and especially the seedlings. A forester now middle-aged recalls "George was the most unselfish man I ever met and he was never too busy to help all young students". All of us treasure the part of George that he passed on to each of us.

G. Wellburn and E. H. Lyons

\section{R. W. LYONS,}

Robert William Lyons was born November 21, 1892 at Lucknow, Ontario. Educated at Lucknow, Clinton Collegiate, and the University of Toronto, he graduated in 1916 with the B.Sc.F. degree. He was employed by the Laurentide Pulp and Paper Company, Grand'Mere, Quebec, 1917-1928, working under the direction of Ellwood Wilson. In 1928 he became Woodlands Manager, Spruce Falls Power and Paper Company, Kapuskasing, Ontario. In subsequent years $\mathrm{Dr}$. Lyons progressed through various positions in the Kimberly-Clark organization to Vice-President and Director of the Corporation.

The Kimberly-Clark Corporation under Dr. Lyons' direction employed over 130 professional foresters. This organization contributed much in the Province of Ontario and in parts 
of the United States to improved woodland policies and forestry practices. He employed foresters in all phases of woods operations. His forward planning included company camps, mechanization, reforestation of cut-over land, better forest protection policies, and improved safety and working conditions for the men.

The profession has lost a leader and many of us a good friend. We all join in extending to Mrs. Lyons our sympathy.

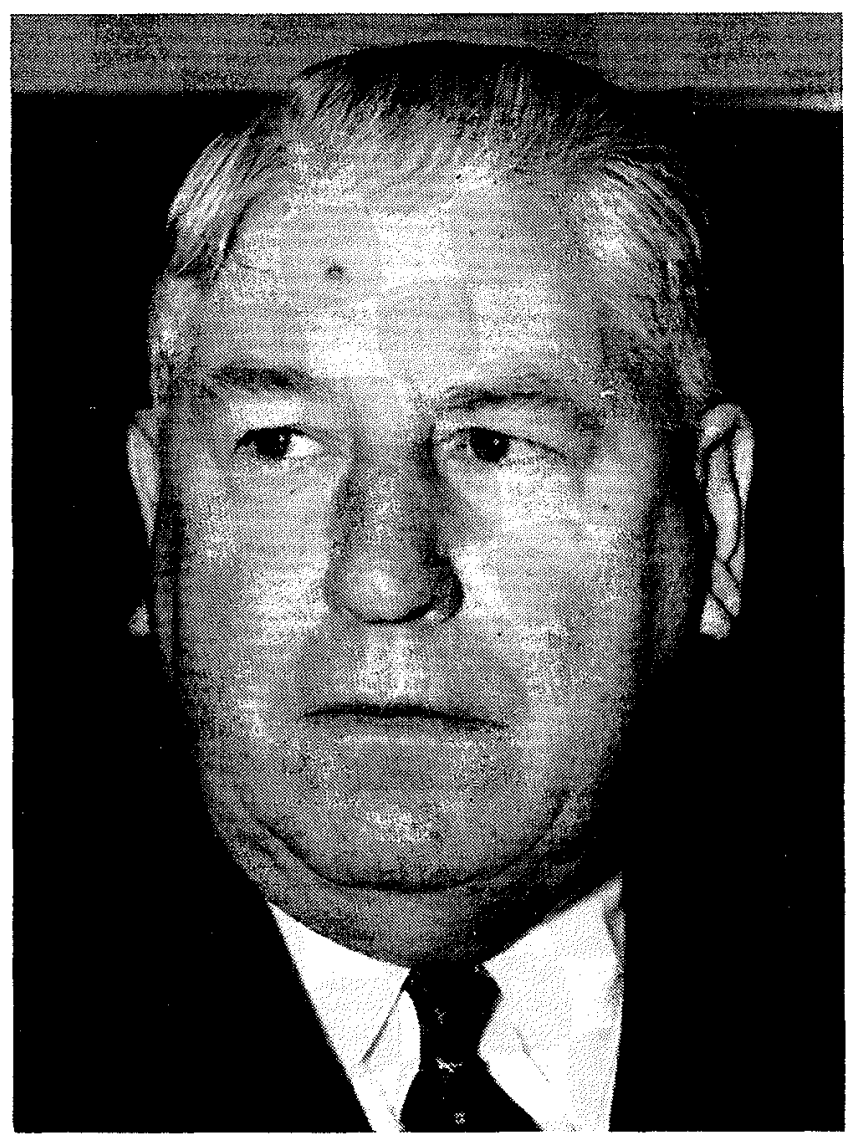

R. W. LYONS

\section{S. W. SCHORTINGHUIS}

On April 5, 1968 S. W. Schortinghuis passed away suddenly at his residence in Winnipeg.

Bill Schortinghuis was born in Winschoten the Netherlands on December 5, 1905 and came to Canada in 1918. He obtained his Forestry Degree from Colorado College in 1928 and joined the Manitoba Forest Service in 1930 as a forester in the Dauphin Region. In 1932 he was appointed forester in charge of the Whiteshell Forest Reserve. In 1950 Bill was granted leave to join the Canadian Army, attaining the rank of major. On his return, he was appointed Chief of Forest Protection and was promoted to Department Engineer in 1951. In 1956 he was appointed Assistant Deputy Minister for the Department of Mines and Natural Resources in which capacity he served until his death.

Bill's long career with the Government of Manitoba has been a distinguished one. He was a tireless worker in the development of the province's natural resources and a highly capable administrator in the Department of Mines and Natural Resources. He liked people and was well liked himself. His informal discussions have often been thought provoking inspiration to many of Manitoba's present foresters.

Bill was very active in the affairs of the Canadian Institute of Forestry and was one of the strongest supporters of the Manitoba Section. In 1950-51 he served as Chairman for the Prairies Section which, in subsequent years, became the Saskatchewan and Manitoba Sections. Bill was Chairman of the Host Annual Meeting Committee for the National Meeting of the CIF held in Winnipeg in 1953 and at the time of his death held the same position for the 1970 meeting also scheduled for Winnipeg.

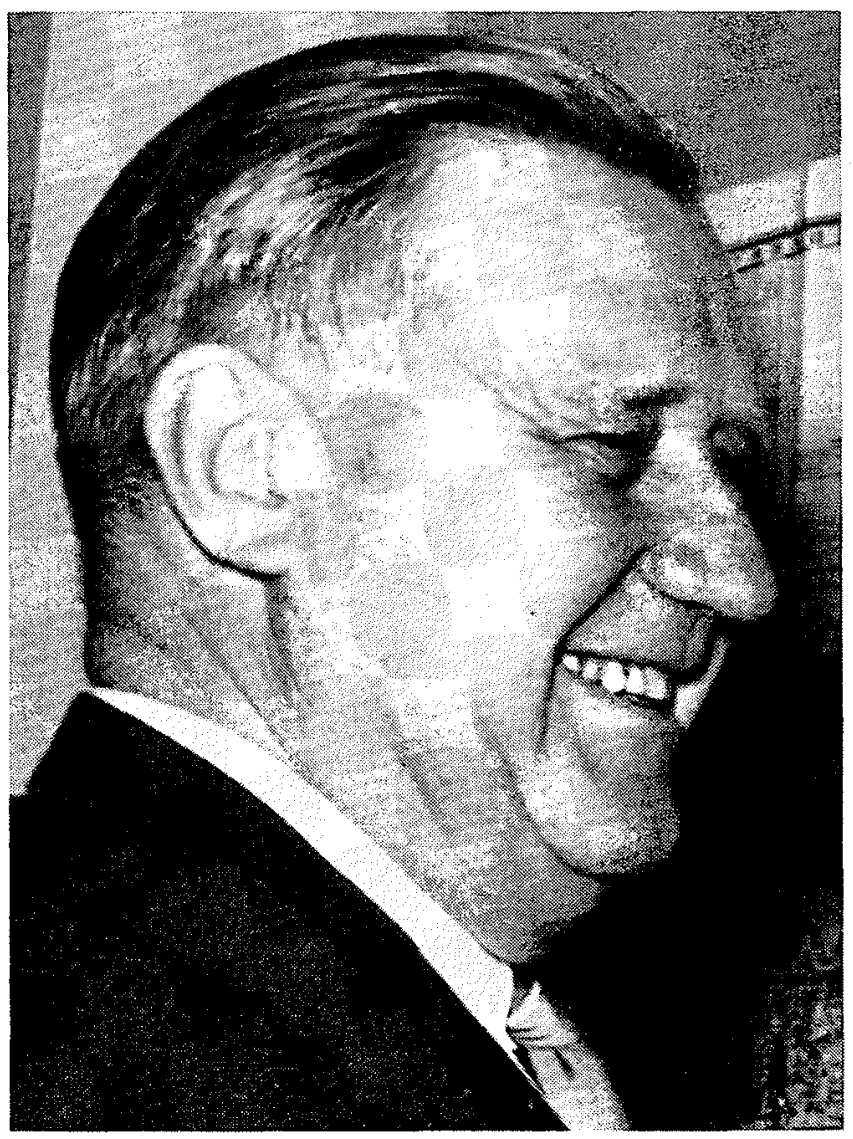

S. W. SCHORTINGHUIS 